\title{
Tourism based Black Economic Empowerment [BEE]: Initiatives for local community development
}

\author{
Lindisizwe M. Magi ${ }^{1}$ \\ Department of Recreation and Tourism, University of Zululand, KwaDlangezwa, 3886, \\ Lmagi@iafrica.com
}

\begin{abstract}
The South African government through a variety of tourism policies and strategies has tried to utilise the Black economic empowerment $[B E E]$ initiative to improve economic benefits for the previously disadvantaged communities. This is to bear in mind that the BEE initiative has been criticised in that "transformation has come to represent a way of compensating previously disadvantaged people, rather than creating opportunities for all citizens to contribute their talents and energies to the process of developing our country" (Ramphele, 2008: 265).

This paper aims at discussing the viewpoints, practicalities and challenges of the tourism related BEE initiatives towards achieving community empowerment and development in KwaZulu-Natal. It also focuses on identifying tourism business opportunities available to the previously neglected communities and social groups. Some of the more specific objectives are: (a) To reveal the extent to which Black people are aware of tourism based BEE opportunities. (b) To establish the levels of tourism stakeholder participation in the BEE initiatives within the study area. (c) To investigate whether the BEE policy is perceived as contributing adequately to tourism entrepreneurship in the study area. It is anticipated that the findings of this study will reflect outcomes that represent the true nature of Black economic empowerment opportunities in the area. It was established that the implementation of BEE policies was not adequately stimulating tourism development, and needed the introduction of a new tourism strategy for entrepreneurial development.
\end{abstract}

Keywords: Black economic empowerment, entrepreneurship, tourism, tourism development, community development, previously disadvantaged communities, stakeholder, strategy, perception.

\section{Introduction}

Among many human economic activities, tourism has come to be regarded as one of the leading revenue generators as well as a good remedy for communities that have been affected by unemployment and poverty. In support of this notion Rogerson \& Visser (2004) have argued that in the last few decades tourism has begun to be recognised as an economic sector with the potential to make a contribution towards the development of communities in tourist destinations. Tourism is envisioned as not only providing sustainable economic betterment of living conditions, but offering social, environmental and ethical factors as support. These factors may translate into poverty alleviation, job creation and reduction of unemployment, which may be seen as constituting community development (Wall, 2000). The BEE initiative was regarded as one of the mechanisms for improving the tourism development process for the local community. The concept of BEE has been defined as a systematic campaign by business and government to improve the financial, social and skills status of previously disadvantaged groups of people in South Africa, by empowering them in areas where they were disadvantaged, neglected, or discriminated [against] (Lubbe, 2003: 27I).

In other words, such BEE initiatives would not be complete without the transformation of tourism policies in the country (Lubbe, 2003; Rogerson \& Visser, 2004). This is to bear in mind that the BEE initiative has been criticised in the following terms. Through BEE:

transformation has come to represent a way of compensating previously disadvantaged people, rather than creating opportunities for all citizens to contribute their talents and energies to the process of developing our country (Ramphele, 2008: 265).

This paper discusses the viewpoints, practicalities and challenges of tourism development which is related to BEE initiatives, in order to help achieve community empowerment and development in KwaZulu-Natal. To achieve this developmental goal and empowerment of communities, the South African government has introduced policies and strategies which sought to create opportunities of economic development, poverty alleviation and community participation. According to Rogerson \& Visser (2004) and Spenceley, Goodwin \& Maynard (2004), some of the most important policy documents include: the White Paper on the Development and Promotion of Tourism in South Africa (DEAT, 1996); Tourism in GEAR (Growth, Employment and Redistribution Strategy (DEAT, 1998); the Transformation Strategy for South African Tourism (DEAT, 2000); the Responsible Tourism Guidelines (DEAT, 2002); the Broad-based Black Economic Empowerment [BBBEE] (DTI, 2004) and Tourism Growth Strategy [SA] 2008-2010 (SAT, 2004). These policy initiatives were the basis for tourism change in South Africa, and Wahab \& Pigram (2000: 28) have argued that

I. Lindisiwe Magi, PhD, is Professor Emeritus and Research Fellow at the University of Zululand. 
"change is a powerful and positive force which, when harnessed constructively, challenges individual, groups and organisations to perform to their optimum capability".

\section{Objectives}

As mentioned earlier, this paper discusses irrationalities or practicalities, described as "myth or reality", associated with tourism related BEE initiatives, that seek to achieve community development and empowerment in KwaZulu-Natal. In the words of Ramphele (2008: 267):

$\mathrm{BEE}$ is meant to give those previously excluded to participate in wealth creation. It is not meant as a reward for being black, a woman or disabled, entitled to benefit without adding any value. BEE is about broadening the base of participation in growing the economy to enlarge the economic cake that can be shared more equitably. We dare not confuse ends and means.

The paper also focuses on identifying tourism business opportunities available for the previously neglected communities and social groups. Some of the more specific objectives are: (a) To reveal the extent to which Black people are awareness of tourism based BEE opportunities. (b) To establish the levels of tourism stakeholder participation in the BEE initiatives within the study area. (c) To investigate whether the BEE policy is perceived as contributing adequately to the tourism entrepreneurship in the study area. (d) To propose a strategic management model that seeks address shortcomings of the BEE initiative in the tourism industry. In this context BEE can be seen as an integrated and coherent socio-economic process that directly contributes to the economic transformation of South Africa and brings about significant increases in the number of Black people who manage, own and control the country's economy (BMF, 2004).

It is anticipated that stakeholders in the study area would be willing to work together in promoting growth and development. Communities seem ready to be educated both linguistically, socially and technically (Magi, 2007; Magakgala, 2003; Ashley \& Roe, 2002). With regard to the listed goals and challenges Young (1973) cited in Wahab (2000: 130) has advised that:

Where there is high unemployment, a relatively unskilled labour and few alternative sources of employment ...

then stimulation of the tourist industry may well be a correct course of action.

It has been acknowledged that about 28 percent of economically active South Africans are without employment, [http:// www.labour.gov.za. (2008)], and tourism could become a major source of employment and foreign exchange, and could ease the balance of payments constraints (ANC, 1994: 107).

\section{Theoretical framework}

There are present-day commentators (BEECom, 200I; Rogerson, 2004; Roberts et al., 2005) who have argued that the current Black Economic Empowerment (BEE) philosophy was developed from the Reconstruction and Development Programme (RDP) (ANC, 19994). The more recent BEE policy is known to have piggybacked on several pieces of postapartheid legislation aimed at correcting past injustices and inequalities, namely, the: Skills Development Act of 1998; Employment Equity Act of 1998; National Empowerment Fund Act of 1998; Skills Development Levies Act of 1999; Preferential Procurement Policy Framework Act of 2000; and later transformed into the Broad Based Black Economic Empowerment Act of 2003/2004 (Bardien, et al. 2006). In addition to these acts, the government has implemented various policies, strategies and programmes, with a view of establishing equitable employment opportunities, and through such means overcoming economic inequalities and underdevelopment.

One of the key approaches to enhance the BEE initiative was the introduction of the BEE tourism scorecard, which gives a measure of the index or percentage share of Black people's ownership, preferential procurement, and capacity building in a tourism entity per specified period (Spykes, 2002). The tourism scorecard is a guide towards that level which BEE in implementation must achieve over a specified number of years. The tourism scorecard is meant to be a monitoring mechanism towards ameliorating the apparent or impending shortcomings of the of the BEE policy. As cited earlier by Rogerson \& Visser (2004); SAGG (2004); and Spenceley, et al. (2004), the tourism industry has not lagged behind in its pursuit of policy and strategy reconfiguration.

Despite the economic successes and a broad range of state policy, strategy and programme interventions aimed at overcoming economic disparities, entrenched inequalities continue to characterise the (South African) economy and act as a deterrent to growth, economic development, employment creation and poverty eradication (DTI, 2003, cited in Rogerson \& Visser, 2004: 324).

3.1 Tourism planning and development

It has been argued that in order to stimulate economic development and job creation, there should be a wellorchestrated programme of tourism planning and development. For the purpose of this study tourism refers to the temporary and short-term movement of people to destinations outside their locality for purposes of entertainment and Inkanyiso, Jnl Hum \& Soc Sci 2010, 2(2) 
enjoyment, with an express view of benefiting the host community. In this regard, tourism is an activity that seeks to benefit all stakeholders in an equitable manner, achieving this objective through the Black entrepreneurial development and Black economic empowerment [BEE] initiatives. According to Mowforth \& Munt (1998) tourism development should reflect the unique circumstances of the region under investigation. The style and scale of development are the basis for planning. The tourism policy should precede planning, as it provides the framework within which planning and development will take place. This manner of thinking also suggests that market forces should not dictate tourism development. Furthermore, Mowforth \& Munt (1998) argue that tourism should be humanised, and not be driven by the greed and ambition of the developers. This implies that it is important that the local communities participate from the very early stages of planning, so as to ensure that their culture and traditions are not ignored. This is one of the methods of forestalling both the greed and the failure within the system to promote Black economic empowerment and the encouragement of Black entrepreneurial development in the tourism industry in South Africa (DTI, 2004a).

It has been argued that the policy on tourism is the prerogative of the government, and as such should be able to benefit all the people of the land. Policy is a dependant variable, depending for its nature on the socio-economic, environmental and political systems. A country that aspires to be a tourist destination should strive to achieve the right policy for the right goals, and policy should not be value-free. There are national values embedded in policy, so if care is not taken, the nation will be stripped off its value system through tourism. It is through such values that the inequalities originating in apartheid in South Africa can be addressed, and Black Economic Empowerment [BEE] policies, which are meant to encourage Black entrepreneurial development, can be established, supported and sustained (DTI, 2004a).

\subsection{South African tourism strategy}

The economic potential of tourism as the key driver of development in South Africa is well documented (Ashley \& Roe, 2002; Viljoen \& Tlabela, 2006; Viljoen, 2007). As such tourism strategic activities should be related to the overall lifeworlds, life cycles and lifestyles of the visitors, if their visit and stay is to be meaningful. Tourism is about good memories, which are the output of its product. The absence of such a product means that good memories and good experience will not be there, which will impact badly on the tourism business (Lubbe, 2003). The foregoing statement suggest[s] that there must be good packaging of the tourism experience which will appeal to and attract local, national and international tourists, who will then make frequent visits to tourist destinations.

\subsection{Involvement of Black people in the tourism industry}

The Broad-Based Black Economic Empowerment [BBBEE] involves Black people through diverse and integrated socioeconomic strategies such as ownership, management, employment equity, skills development, preferential procurement, enterprise development, and corporate social investment. The tourism White Paper (DEAT, 1996) has acknowledged that there are hindrances towards the full involvement of Black people in the tourism industry. The BEE challenges show that there is a need to develop further plans in order to ensure that BEE is more inclusive.

The DTI (2004b) findings have revealed that BEE has not adhered to the aims of its foundation. There is not enough involvement of Black people in the tourism businesses. If the BEE implementation strategies had been properly pursued business opportunities would be accessible to more Black people. It has been argued that access to opportunities should be more inclusive. The inclusive BEE allows the entrance of Black people while maintaining the existing tourism businesses. The inclusive BEE according to the DTI (2004a) wishes to meet the following set of objectives:

- Promoting economic transformation to enable a meaningful participation of Black people in the economy.

- Increasing the extent to which Black women own and manage existing and new enterprises, and increasing their access to economic activities, infrastructure and skills training;

- Promoting investment programmes that lead to Broad-Based and meaningful participation in the economy by Black people in order to achieve sustainable development and general prosperity;

- Empowering rural and local communities by enabling access to economic activities, land, infrastructure, ownership and skills, and;

- Promoting access to finance for Black economic empowerment

The more inclusive BEE is referred to as the Broad-Based BEE. As stated in the Broad-Based BEE Act of 2003, it means the empowerment of all Black people, in particular women, workers, youth, and people with disabilities. Inclusive BEE programmes would be very helpful in the study area because the level of unemployment of the youth and women, is particularly high [www.en.wikipedia.org/wiki/broad_based_black_economic_empowerment (2007)].

In this study, additional constraints against the increase of Black participation and ownership in the tourism industry are identified as follows:

- The existence of corrupt practices in the tourism industry.

- Access to opportunities for politically connected Black people. There is less focus on the wide society. 
- The Black people's attitude towards the tourism sector. Tourism is considered as the White people's thing.

- The material resources required to acquire ownership are expensive.

- Access to finance remains a challenge.

- The literacy level among the Black people is low.

- There is a lack of entrepreneurial skills, in particular among the Black population.

Regarding the Black Economic Empowerment [BEE] policies and Black entrepreneurial development initiatives, in the context of the study area there are unequal tourism infrastructural provisions. In some White suburban areas there are adequate infrastructural developments. But in Black suburban areas there is a lack of infrastructure such as access to roads, electricity, running water and modern communication technology. The lack of infrastructure in these areas inhibits tourism entrepreneurship potential, which is only practicable in the main city.

\subsection{Black access to tourism opportunities}

An important question which needs to be asked concerning the poor participation of Black people in the tourism industry is whether Black people have the means to access, participate in and succeed in this industry. Do Black people have the opportunities, skills, facilities and land to practice tourism activities, in the first place? It is the view of this research paper that government should play a legislative and facilitative role in promoting the BBBEE policies and Black tourism entrepreneurial development. The absence or lack of Black participation, attainable opportunities, skills, facilities and land resources, presents a challenge to the researcher. The latter is the fundamental objective of this research study: to reveal the awareness of and participation level of Black people in the tourism entrepreneurial opportunities; and to investigate the implementation of policies and strategies for the delivery of tourism entrepreneurship in the study area.

\subsection{Employment equity and skills development}

Current trends in employment equity highlight the alignment of skills development in achieving the objectives set out in the national skills strategy of the South African government. From these trends, it is clear that the management profile of Black people and women in the top echelons of decision-making are still very small. To determine the situation of employment equity [EE] in the study area is not an easy task. Williams \& Shaw (1998: 44) revealed that employment in tourism is difficult to measure on the basis of official statistics. Direct employment agents such as hotels, restaurants and transport do not have accurate statistical records, and therefore it becomes very difficult to determine the employment statistics in the indirect tourism businesses. However, Vivian \& Hall (1994) have established that the majority of jobs in tourism, especially those of low skill and wage are occupied by women. There is a need to enable women to occupy jobs in higher positions. The BMF points out that the current monitoring mechanism by government has failed to meet BEE objectives. This kind of conclusion has serious implications for the development of Black entrepreneurship objectives of the state and metropolitan local authorities.

3.6 Challenges in tourism business development

The White Paper on tourism development (DEAT, 1996) mentions the following constraints towards tourism development:

- Limited integration of local communities and previously neglected groups into the tourism industry.

- Inadequate tourism education, training, and awareness.

- Lack of inclusive, effective national, provincial, and local structures for the development, management, and promotion of the tourism sector.

- Lack of information and awareness, lack of expertise and training, lack of interest on the part of existing establishments to build partnerships with local communities and suppliers.

- There is the concern from the Black people that tourism is the White man's thing and not for them; tourism is perceived as catering to the predominantly White upper middle classes, and is not within reach of the previously neglected.

- The majority of South Africans have never been meaningfully exposed to the tourism industry. Many communities have little access to natural and cultural resources.

From the above factors, it can be seen that tourism education and training can be considered as the core of the solution towards involvement of Black people in the tourism industry. The business sector is expected to play an empowering role for young up-and-coming Black entrepreneurs and the implementation of the government BEE policy. According to Aylward \& Lutz (2003:I5) the private sector's share of the tourism industry is about $88 \%$ as compared to II\% of the share of the public sector. The majority of tourism associations support and play an active role in Black economic empowerment. However, some of the national tourism associations find it difficult to implement BEE, suggesting that the nature of their business is a limiting factor.

Inkanyiso, Jnl Hum \& Soc Sci 2010, 2(2) 
According to Spykes (2002), tourism business associations in South Africa have shown a commitment to transformation. There is a particular interest in introducing affirmative procurement. Nevertheless, there are indications that private sector companies have some difficulty complying with BEE. Some of the complications faced by the tourism businesses include the following:

- The lack in empowerment procurement measurement.

- Smaller companies do not have procurement departments.

- Affirmative procurement entails establishing new information systems, modifying existing ones, or reorganising the company's procurement function.

These challenges demand further financial resources from tourism businesses that may not be available. The government should look at supporting those businesses committed to transformation and implementation of the BEE. In this regard, the state has introduced a new empowerment strategy known as the accelerated and shared growth initiative for South Africa (ASGISA). The aim of ASGISA is to bridge the gap between the two economies existing in South Africa. These two economies comprise the well-off and privileged in the first economy and the poor, unemployed and marginalised in the second economy. Another characteristic of the second economy is its need to access funding (DEAT, 1998).

The Government's poverty alleviation programmes, including rural development programmes, integrated security programmes and extended programmes on job creation, have appealed for partnerships with business and community based organisations. This cooperation could lead to a more effectively managed Black tourism entrepreneurship initiative, which would benefit the previously disadvantaged community. Community participation in decision-making is paramount in ensuring the acceptability of tourism goals, and this is a universally accepted strategy (Wahab, 2000). According to Cowan, et al., (2003) there are various strategies being pursued in South Africa, which seek to ensure socio-economic redress and compensation in the tourism landscape. Some of these include: initiation of community-based enterprises; active participation in tourism development; empowerment of community structures and community involvement in planning, implementation and management (DEAT, 2006).

\subsection{Current Viewpoints by BEE Visionaries}

There is a general perception among the young, up-and-coming, Black potential entrepreneurs that the BEE initiative is not doing very well. A significant number of business people and writers (Bain, 2006; Lediga, 2006; Mabotja, 2006; Monama, 2006; Ryan, 2006, Sikhakhane, 2006, Jack,2008; Milazi 2008) argue at various levels that if BEE is to thrive and be sustained, then the government and the private sector have to play a more meaningful role in this initiative.

According to Lediga (2006), notwithstanding that there has been some progress in the participation of Black people in the South African economy, the process has been fraught with some major shortcomings. The shortcomings include the following:

- There has been a deluge of empowerment deals worth billions of rand, which are not necessarily covering broadbased BEE needs.

- There are many senior Black people that are in non-executive directorships, yet there are very few executive directors. The non-executive directors are really not involved in the day-to-day running of the business.

- The main issue is that Black talent is focused on deal-making in already existing companies, rather than Blacks engaging in starting and building their own enterprises.

- That if Black people are to be permanently integrated into the economy, they should be building business for themselves and their future.

- The immense potential of procurement to grow Black business has been seriously undermined by 'fronting': this is the practice of Blacks acquiring business for White companies, pretending to be part of the ownership of that White company.

- Access to skills is a major predicament for the Black economic empowerment and the Black entrepreneurial development initiatives. There is a need to continually improve the managerial skills of entrepreneurs, especially in collaboration with universities.

In summing up what Lediga (2006: 10) has to say about the general problem of BEE policy implementation and its attempt at initiating Black entrepreneurial development in South Africa, the BEE charter has shortcomings. He argues (2006:10):

The problem with this is that Blacks are given fish and are not taught how to fish. Empowerment should not happen at the expense of entrepreneurship. We need to ensure that Black operational entrepreneurs play a more meaningful, visible and exalted role. 
Other viewpoints from BEE participants with intent to improve Black economic empowerment and Black entrepreneurial development include those from (Bain 2006; Mabotja 2006; Monama 2006; Ryan 2006; Sikhakhane 2006; and Milazi 2008), who argue that:

- The empowerment policy is an experiential or learning process - it is evolving based on these tensions. There is no real model anywhere else in the world we can take from. South Africa has continually improved on the existing model in order to achieve ultimate success in several decades (Ryan, 2006).

- The reason the current state of mind is disappointing is that there was hope that forerunners would become role models for the Black youth, showing them that given the opportunity, Black people are as capable as any other group to make it in the business world (Sikhakhane, 2006).

- Based on these shortcomings Black entrepreneurs are inhibited by the following: Lack of capital or funding to purchase a stake in existing business; Scarcity of start-up capital for own business; Lack of managerial experience to creating own wealth; Over-dependence of government hand-outs to initiate Black entrepreneurial development (Sikhakhane, 2006).

- If empowerment has to be successful and sustained in South Africa, companies need to find imaginative ways to find empowered suppliers to meet procurement aims. These aims have to be in-sink with DTI's scorecard which provides 20 points for procurement from BEE enterprises (Ryan, 2006).

- Superior contributors to BEE are companies that display internally a positive commitment to all seven empowerment indicators of the broad-based BEE score card. These include: equity ownership, management and control, employment equity, skills development, preferential procurement, enterprise development and residual factors (Corporate Social Responsibility) (Monama, 2006).

- Empowerment is about choosing White partners very carefully - empowerment should not be regarded as easy money,it is not selling of a black skin, but selling of black brain. Empowerment is a means to an end and not an end in itself (Zungu cited by Bain, 2006)

All these current viewpoints cited by BEE visionaries and commentators suggest that the implementation of a viable and ustainable Black Economic Empowerment [BEE] policy and Black entrepreneurial development initiatives needs to be considered in relation to the pointers given above. The words of Mandela during the presidential address at his inauguration are pertinent in this regard (Sikhakhane, 2006: 16):

The task at hand will not be easy. But you have mandated us to change South Africa from a country in which the majority lived with little hope, to one in which they can live and work with dignity, with a sense of selfesteem and confidence in the future.

There is the question whether BEE can really be broad-based in a capitalistic society (Qunta, 2004). There is concern over the procurement consultants and advisors who are predominantly White who, according to Lalu (2004) stand in the way of the introduction of Blacks in economic empowerment activities. Ending corruption is considered as one of government's challenges, as are developing Black capacity regarding BEE deals, and the access to finance.

\section{Delimitation and methodology}

As a way of demonstrating how tourism development is attempting to achieve its mandate through the BEE initiatives, with a view of achieving community empowerment, this paper discusses the outcomes of empirical findings from two study areas. These study areas - the Durban Metropolitan Area and the Richards Bay-Empangeni Area [Refer to Figure I], are both leading tourist centres on the Eastern Coast of KwaZulu-Natal. They provide tourists with many attractions ranging from urban, industrial, natural, cultural and heritage tourism. The Durban Metropolitan Area specialises in urban based tourism and Richards Bay-Empangeni in nature-based tourism. Both areas have high levels of unemployment and poverty, and require an improved process of tourism development and delivery through Black economic empowerment.

This research paper reports on the studies undertaken in the Durban Metropolitan Area [DMA] and the Richards BayEmpangeni Area [REA] (Vilakazi, 2008; Biyela, 2002). The stratified random sample-size of the case study areas were I78 for the DMA and 120 for the REA. The samples were categorised into stakeholders such as: Black entrepreneurs; tourism and government officials, and local community and public. The respondents had provided information on matters relating to their: socio-economic status, participation in tourism, awareness of tourism business opportunities, Black tourism entrepreneurial policies, tourism opportunity and tourism strategic management practices (Vilakazi, 2008; Biyela, 2002).

\section{Discussions of findings}

The basic intention of this paper is to establish if the original aim of the BEE policy or initiative that of transforming the entrepreneurial or economic possibilities to benefit the previously disadvantaged communities, is being achieved. As well

Inkanyiso, Jnl Hum \& Soc Sci 2010, 2(2) 
as revealing the stakeholders' perceptions about some of the negative pronouncements of the BEE visionaries and commentators. Some of these are that the BEE initiative is:

- Meant to give the previously excluded an opportunity to create wealth for their betterment.

- Supposed to broaden the base of Black participation in the tourism economy of South Africa.

- Not doing well and that as an economic process it is fraught with some major shortcomings.

- Not a fool-proof tourism model but there is none anywhere else in the world we can take (Ryan, 2006).

\subsection{Awareness of tourism based BEE opportunities}

One of the objectives of the research studies was to reveal the stakeholders' awareness of the BEE opportunities in their areas. The term 'stakeholder' was broadly defined to refer to all participants in varieties of tourism activities or simply as tourism industry participants [www.tourismvi.ca/org/stakeholder, (2008)]. Perceptions of the stakeholders therefore become important in this instance, since they assist in identifying the expectations of local communities about Black tourism entrepreneurial development possibilities (see Figure I).

Of the stakeholders in the Durban Metropolitan Area [DMA] and the Richards Bay-Empangeni Area [REA] responding to the principle of awareness, the majority [68\% in DMA and $30 \%$ in REA] indicated that they were fully aware of the tourism entrepreneurial opportunities for Blacks in their areas. The justification for this response is that DMA respondents were fairly well educated and obviously do read newspapers about what is going on in the tourism industry. On the other hand, $64 \%$ of the REA respondents were unaware of the BEE tourism opportunities, mainly because the sample was less educated and there are fewer newspapers in this area. On the other hand, $24 \%$ and $8 \%$ of the DMA respondents were not aware of or not sure of opportunities.

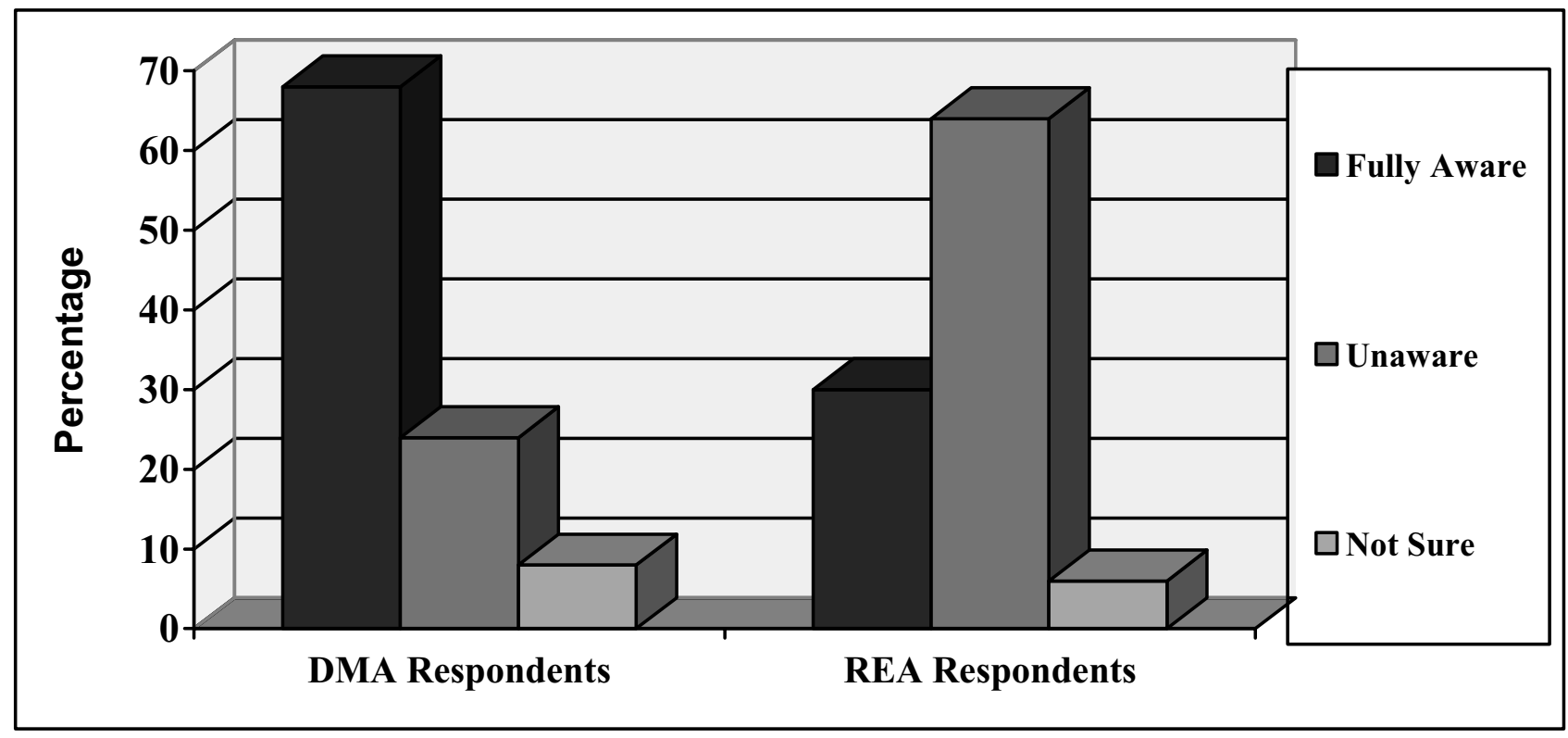

[n = I78 DMA and $\mathrm{n}=164$ REA]. [Source: (Vilakazi, 2008; Biyela, 2002)].

Figure 1 Awareness of tourism BEE opportunities for blacks

It is also possible that a significant number of the respondents [REA $=64 \%]$ who were unaware of the existence of BEE tourism opportunities in the study area could be from local communities staying in townships, who may be less exposed to BEE related opportunities. These respondents are inhibited by: (a) lack of skills and education about BEE related tourism; (b) scarcity of start-up capital for their business venture; and (c) overdependence on government hand-outs to initiate Black tourism development (Sikhakhane, 2006).

It may also be argued that if the BEE policy, supporting the tourism development opportunities for Blacks, were to be successful and eventually beneficial to the local people of KwaZulu-Natal, it would have to be better understood and 
recognised by the local communities, and not only by the government and the business sector, as is seemingly the case now.

5.2 Understanding the aims of BEE entrepreneurial opportunities by age

Age is an important factor in determining the understanding and participation of Black tourism stakeholders in the BEE related tourism development initiatives in the study areas. It has been argued that the younger people are more involved in participating in politically aligned BEE tourism activities, and some of these persons have been hired to procure lucrative BEE deals (Dawes, 2004). Furthermore, Spykes (2002) confirms that the problem of fronting has been highlighted in several sectors but still remains difficult to solve, so long as the demand for empowerment of Black business partners exceed their supply.

In an attempt to address how age plays a part in influencing the BEE tourism development processes, the respondents were asked to answer questions relating to their understanding of the BEE policy in terms of age. The participants were categorised as follows: young adults 15-35, mature adults 36-50, and old adults $5 \mathrm{I}-80$. The majority of young respondents [63\% in DMA and 62\% in REA] indicated that they had good understanding of the aim and intention of the BEE policies for tourism development. In other words the young adult group was more positive about understanding the aim of the BEE policies.

Furthermore, it became apparent that a significant number of the old age group [ $44 \%$ in DMA and $51 \%$ in REA] indicated that they were not sure about the aims of the BEE policy. The main justification of these findings could be that the young adults were more in step with the new policies of the democratic government in South Africa than the old age group. The older group is perhaps less politically connected and is on the grounds of its age-group disinclined to run after business deals and tenders, as is usually the case in acquiring BEE related tourism entrepreneurial opportunities.

\subsection{Stakeholder participation in the BEE initiatives}

Earlier in this study reference was made to the fact that there were many factors that can limit the meaningful involvement of Black communities in tourism and the tourism industry, particularly as it relates to BEE policies for tourism development (DEAT, 1996). The purpose of this research study, among other things, was to seek to establish how stakeholders perceive Black participation in BEE tourism initiatives in the study areas. According to Pigram (1983) participation can be defined as those activities by which members of society engage in the selection of decision-makers and authorities that would involve themselves in the formation of tourism public policy. This public policy would encourage the community to get involved in tourism and related businesses. In other words, in this context, participation may be used to determine how stakeholders perceive the level of participation in BEE related tourism development initiatives in the study areas.

The responses of stakeholders depicted in Figure 2, show that, on the whole, there is a low participation rate among the entrepreneurs [ $47 \%$ in DMA and $58 \%$ in REA] and community [52\% in DMA and $40 \%$ in REA]. On the other HAND, there is high participation in BEE initiatives among the officials in both the DMA and REA study areas. What is also interesting is that a significant number of community members [34\% in DMA and $32 \%$ in REA] indicated that they are 'not sure' about rates of participation in BEE related initiatives.

It is important to note that the entrepreneurs did not necessarily base their level of participation on the basis of successes achieved in BEE related projects, but simply that they are on hand to participate. Research observers have indicated that many entrepreneurs and community members are called but very few are chosen, in other words, it remains difficult to get assistance and tenders (Spykes, 2002; Dawes, 2004; Lediga, 2006; Monama, 2006; Sikhakhane, 2006).

Not surprisingly, the majority of officials felt that their participation in BEE related tourism development activities was intense and positive, since it was their mandate to promote BEE policies in the study areas. A small percentage [25\%] of the officials indicated that they were not participating in BEE policy activities. Finally and importantly, the local community showed a reverse distribution of what the entrepreneurs indicated. The main reason for the negative responses were that many of the local communities were not well educated about and adequately exposed to participation in BEE tourism ventures, as well as about the development and management of the tourism BEE related activities in the study areas.

Inkanyiso, Jnl Hum \& Soc Sci 2010, 2(2) 


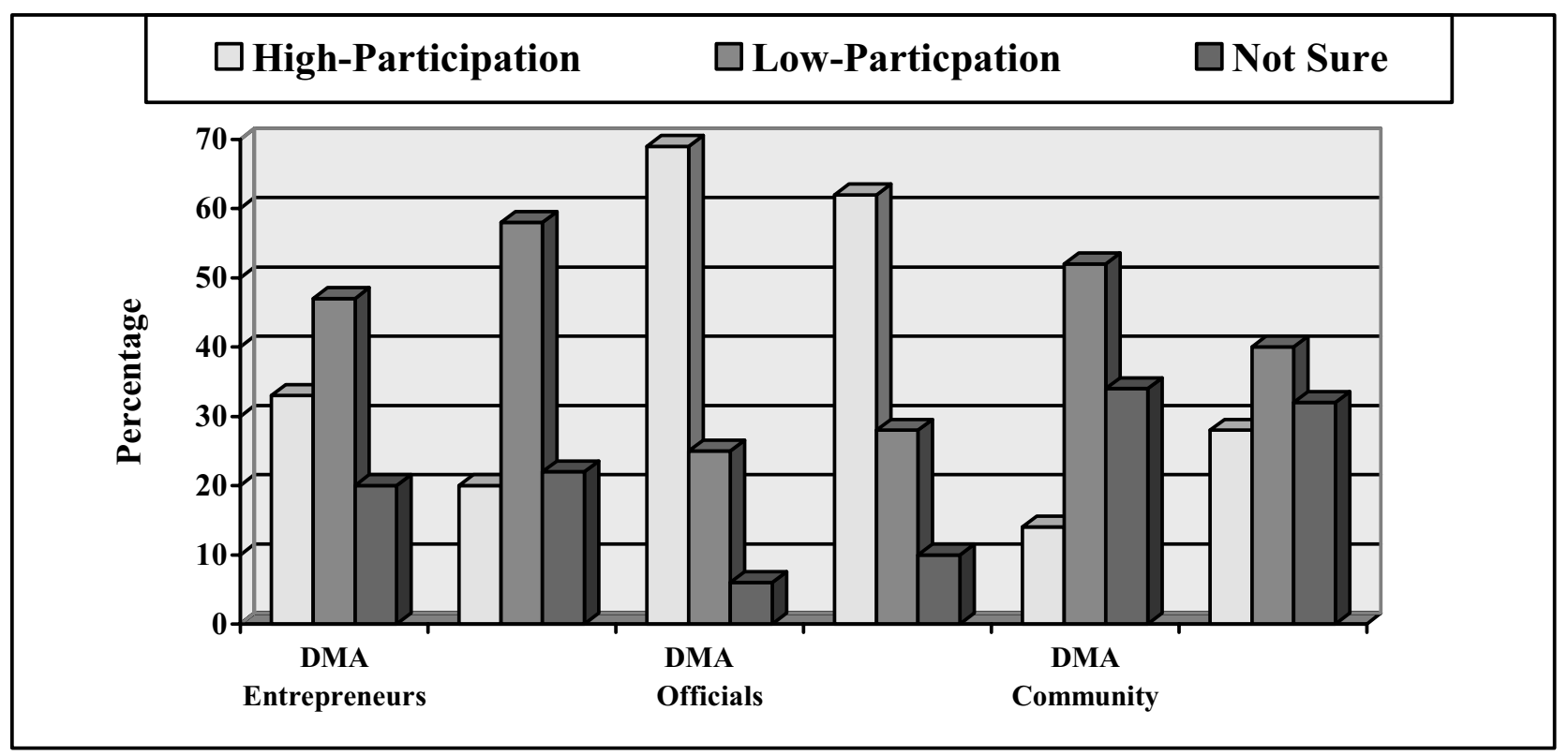

$[n=178$ DMA and $n=164$ REA]. Subjects gave more than one response for each question.

[Source: (Vilakazi, 2008; Biyela, 2002)].

Figure 2 Stakeholder participation in BEE related initiatives

\subsection{Policy contributions to tourism entrepreneurship}

There have been tremendous arguments, contestations, acceptances and rejections of the BEE policy initiatives in the literature (Dawes, 2004; Lalu, 2004; Matola, 2004; Bain, 2006; Lediga, 2006; Mabotja, 2006; Monama, 2006; Ryan, 2006, Sikhakane, 2006; Jack, 2008). Some views hold that the BEE policy initiatives are not successfully contributing to the tourism entrepreneurial development of Black communities. In fact, according to Dawes (2004) there is still a contention that currently beneficiaries of the BEE policy are a selected few. BEE is viewed as benefiting only an "elite Black" SECTOR. Dawes (2004) further opposes what he calls the conflict of interests, where only the prominent Black politicians benefit from Black empowerment initiatives. The apparent limited number of Black people's involvement in BEE initiatives can also be blamed on their lack of business management capacity and experience.

Pursuant to the argument on the "conflict of interests" commonly practiced in the study area, this paper sought to establish the extent to which the BEE policy contributes to legitimate tourism development in the area. In this context, Figure 3 shows some of the stakeholders' perceptions regarding BEE policy contributions towards tourism development in the study areas. The question was, are the policy contributions or inputs of a high order or low order of tourism development or entrepreneurship? The analyses on the three stakeholder groups: entrepreneurs, tourism officials and community members, reveal results that are focused in one direction. The majority of entrepreneur-respondents [46\% in DMA and $47 \%$ in REA] indicated that they perceived the BEE policy inputs or contributions towards tourism entrepreneurship to be low, and a significant number [21\% in DMA and $28 \%$ in REA] supported the negative perception by saying they were 'not sure' of the situation.

Similarly, the majority of tourism officials and local community members [ $48 \%$ and $63 \%$ in DMA, as well as $25 \%$ and $63 \%$ in REA] respectively, perceived the contribution of BEE policies towards tourism development to BE of a low input. The reported reasons for the negative response were that stakeholders had experienced difficulties in trying to access the BEE tourism development opportunities in VARIOUS areas. Furthermore, it could be that the negative reports in the media and literature had impacted negatively on many community members. These negative reports relate to: selective and preferential treatment towards accessing BEE deals; dependence on political affiliation, the fronting syndrome, emerging entrepreneurs are not supported, lack of capital or funding to purchase BEE stakes in existing business, poor skills development planning, over-dependence on government hand-outs, and unemployment (Spykes, 2002; Bain, 2006; Peacock 2006a, 2006b; Ryan, 2006, Sikhakhane, 2006; Milazi, 2008). Finally, the respondents seem to support the view that it is unfortunate that the whole Black economic empowerment trajectory is dependent on giving opportunities to the 
learned, connected and mighty. It is not meant for the ordinary, the poor, up-and-coming Black people with entrepreneurial expectations. Therefore, much work still has to be done in transforming the business landscape (Dawes, 2004; Lediga, 2006; Monama, 2006).

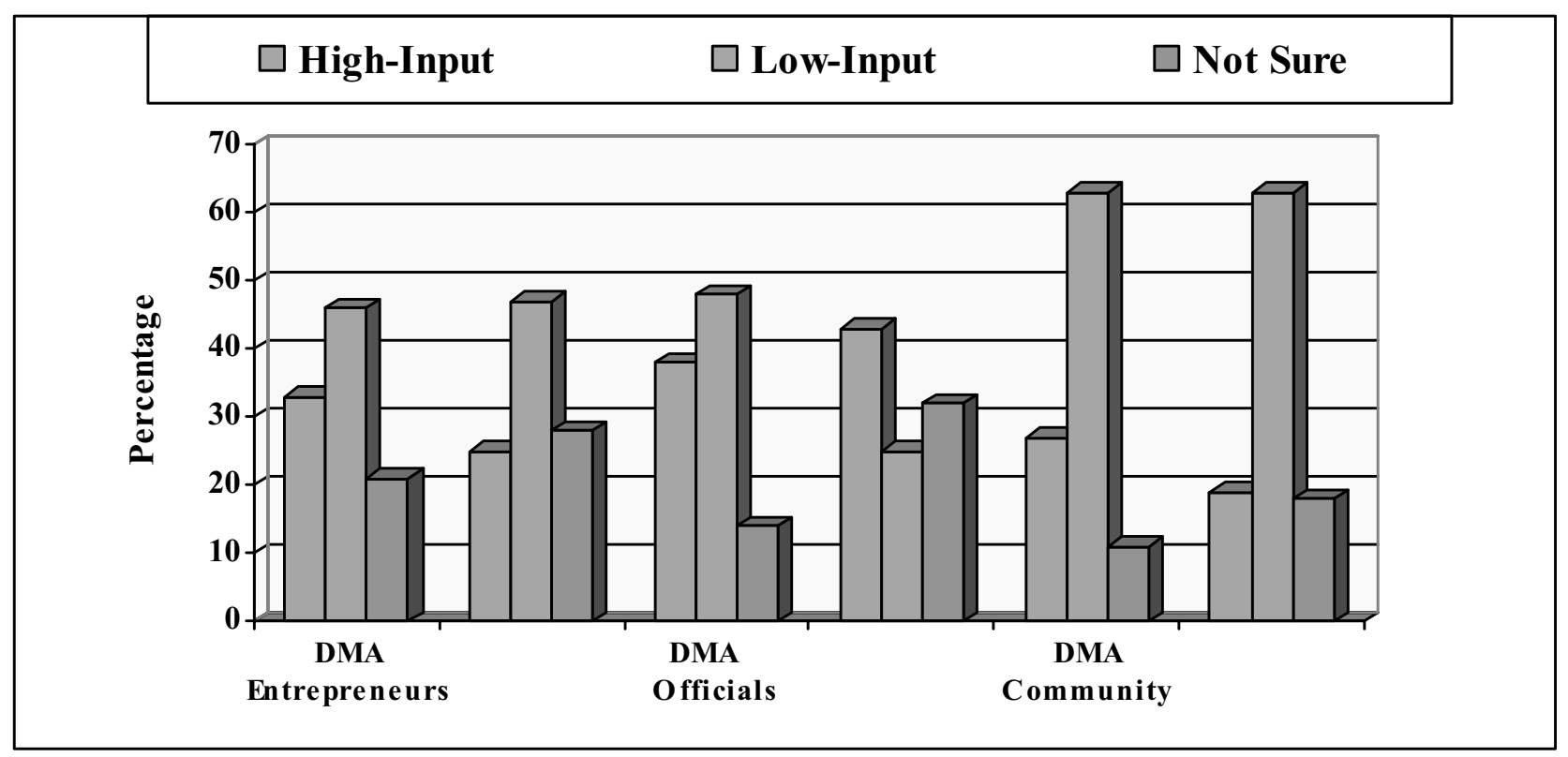

$[n=178$ DMA and $n=164$ REA]. Subjects gave more than one response for each question.

[Source: (Vilakazi, 2008; Biyela, 2002)].

Figure 3 Perceived Contribution of BEE Policy to Tourism Entrepreneurship

Similarly, the majority of tourism officials and local community members [ $48 \%$ and $63 \%$ in DMA, as well as $25 \%$ and $63 \%$ in REA] respectively, perceived the contribution of BEE policies towards tourism development to BE of a low input. The reported reasons for the negative response were that stakeholders had experienced difficulties in trying to access the BEE tourism development opportunities in VARIOUS areas. Furthermore, it could be that the negative reports in the media and literature had impacted negatively on many community members. These negative reports relate to: selective and preferential treatment towards accessing BEE deals; dependence on political affiliation, the fronting syndrome, emerging entrepreneurs are not supported, lack of capital or funding to purchase BEE stakes in existing business, poor skills development planning, over-dependence on government hand-outs, and unemployment (Spykes, 2002; Bain, 2006; Peacock 2006a, 2006b; Ryan, 2006, Sikhakhane, 2006; Milazi, 2008). Finally, the respondents seem to support the view that it is unfortunate that the whole Black economic empowerment trajectory is dependent on giving opportunities to the learned, connected and mighty. It is not meant for the ordinary, the poor, up-and-coming Black people with entrepreneurial expectations. Therefore, much work still has to be done in transforming the business landscape (Dawes, 2004; Lediga, 2006; Monama, 2006).

\subsection{Strategies for enhancing tourism development opportunities}

On the one hand, the contribution of the BEE initiatives towards tourism development has been measured by improving the participation of Black people in business (De Villiers, 2005). On the other hand, the strategies for enhancing tourism development opportunities can be assessed, on the basis and success rate of tourism strategies, such as a skills training strategy; job creation strategy; employment strategy; financing strategy; equity ownership strategy; communication strategy; marketing strategy; service excellence strategy; Black employee procurement strategy and community empowerment strategy. The analysis of the enhancement of these tourism opportunities is restricted to the Durban Metropolitan Area [DMA] only, and not the REA. The testing of these competitive strategies is based on two opinions doing the rounds in the BEE environment: (a) That, notwithstanding a decade's existence of the BEE policies, there have been negative reports and poor levels of achievement stemming from the BEE process (Nzimande \& Sikhosana, 1996; Matola, 2005; Lediga, 2005). (b) That the legislation of BEE policies has ushered in some measure of economic benefits to 
the Black entrepreneurs in South Africa (DTI, 2004a). Furthermore, that the majority of stakeholders have viewed BEE as a viable policy to address inequalities from the past.

For the purposes of this paper only three of the ten strategies were analysed. These are skills-training strategy, employment/job creation strategy and financing strategy, which are aimed at revealing the effectiveness of existing competitive strategies for enhancing tourism development opportunities. According to the Tourism White Paper (DEAT, 1996) adequate training in tourism will not only increase processes of job creation and employment, but also stimulate the transformation process, particularly in the BEE regime. One of the main principles governing the approach to job creation and employment is to encourage the tourism private sector to increase its commitment to formal training as well as on-the-job training, also called in-service training. The promotion of such a principle makes it possible for the BEE related tourism development opportunities within the Durban Metropolitan Area [DMA] to be more committed to existing competitive strategies that seek to enhance the tourism industry.

What is shown in Figure 4 is the outcome of perceived strategies for enhancing tourism development in the DMA. On the whole, the majority of the respondents perceived skills-training [58\%], employment/job creation [62\%] and financing [67\%] strategies as not enhancing the tourism development opportunities. On the whole, only less than $15 \%$ of the respondents expressed a positive attitude towards tourism enhancement. The BMF (2003) has reported that three key areas ought to be attended to, if the skills training strategy were to enhance tourism development: the monitoring compliance with employment equity; skills development with the purpose to develop capabilities and to empower people to be able to make decisions; and making funding available for enhancing tourism development.

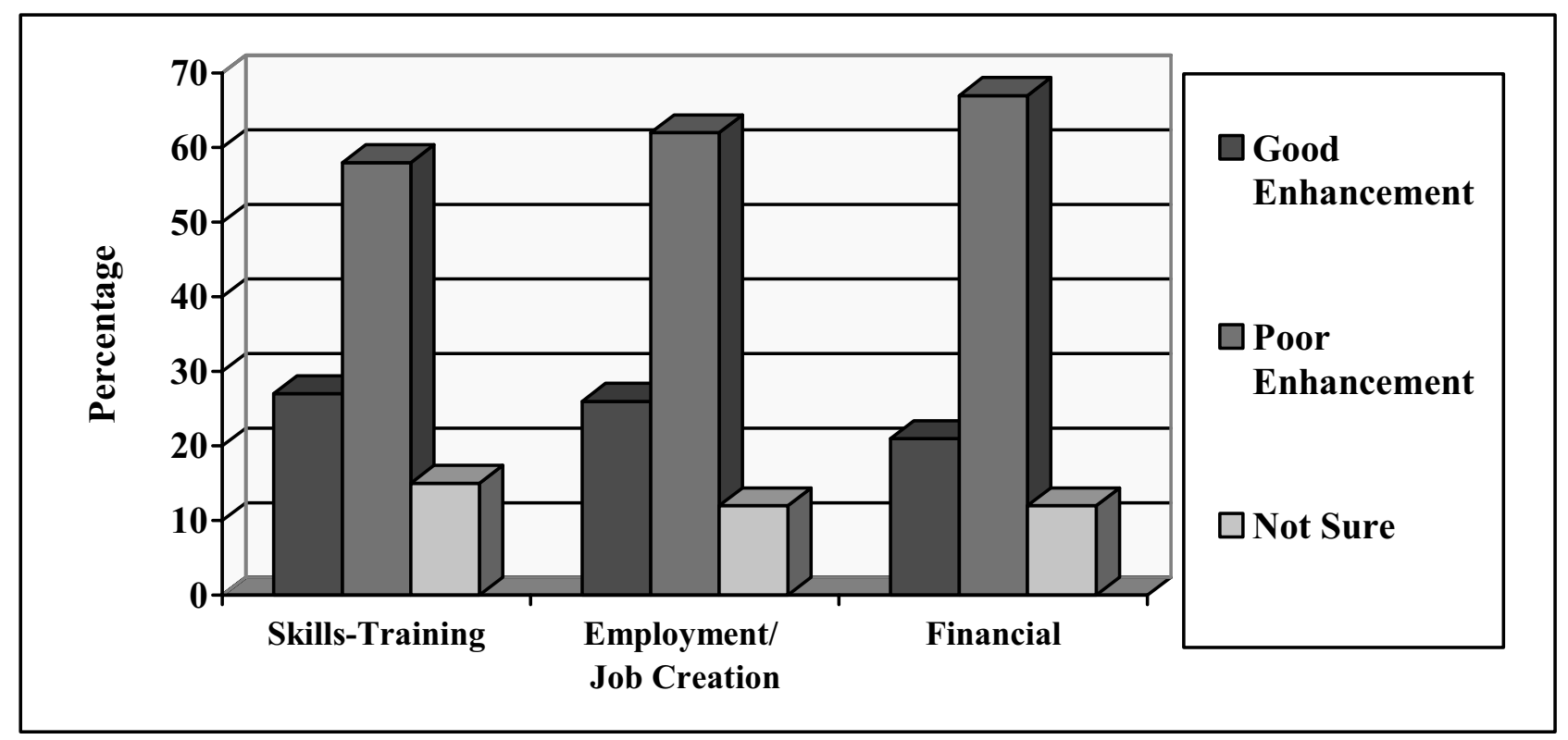

$[n=178$ DMA and $n=164$ REA]. Subjects gave more than one response for each question.

[Source: (Vilakazi, 2008; Biyela, 2002)]

Figure 4 Perceived Strategies for Enhancing Tourism Development Opportunities

The high increases in unemployment in the DMA account for expressed negative responses, which are supported in the views of Spykes (2002) when he argues that some of the challenges threatening the tourism industry are: the lack in empowerment procurement measurement; smaller companies are without procurement departments; and that affirmative procurement entails establishing new information systems, modifying existing ones, or reorganising the company's procurement function. To improve the rate of Blacks entering the tourism industry, the following have to be observed (DEAT, 1996):

- The government must improve Black access to finances.

- A dedicated tourism development fund must be established.

- State funding must be accessible to the business community.

- Loans to small enterprises and entrepreneurs must be guaranteed.

- Corrupt practices in business must be eliminated (Spykes, 2002). 
The outcomes of the analyses covering the state of awareness, participation, and contribution to tourism and its management, point to the fact that the present BEE tourism development strategies are not adequately enhancing the state of the industry. We may therefore conclude that the tourism transformation envisaged by the government and business sector, seems to falter in becoming a respectable way of compensating the previously disadvantaged communities. Rather, as mentioned earlier, it has come to be synonymous with "theft by the Black affluent"

\section{Conclusion}

This paper has attempted to argue for a more equitable and viable BEE tourism development initiative or strategy, which would benefit the previously disadvantaged communities in the study areas. The outcomes expressed in the paper, relating achieving Black economic empowerment, skills development, employment equity and acquisition of financial assistance, as perceived by stakeholders in their areas, are reflecting an inconclusive story that needs more investigation. The paper holds the view that the delivery of the BEE-related tourism initiative, which is meant to benefit the previously disadvantaged communities, still needs to be improved.

\section{References}

ANC, [African National Congress], 1994: The Reconstruction and Development Programme: A Policy Framework. Johannesburg: Umanyano Publishers

Ashley, C. \& Roe, D. 2002: Making tourism work for the poor: Strategies and challenges in South Africa. Development Southern Africa. 19 (I): 6I-82.

Aylward, B. \& Lutz, E. 2003: Nature Tourism in Kwazulu-Natal South Africa. Washington, DC: World Bank.

Bain, J. 2006: Zungu quietly building the Zico empire. Sunday Times: (Business times). 10 September, 2006.

Bardien, G.; Mohamed, L.G. \& S. Roberts. 2006: An investigation into BEE in the metals sector of the economy. School of Economic \& Business Sciences, University of the Witwatersrand, Johannesburg.

BEECom [Black Economic Empowerment Commission]. 200 I: BEECom Report. Skotaville Press, Johannesburg.

Biyela, C. S. 2007: The potential of Black economic empowerment policy in promoting tourism entrepreneurship in the Umhlathuze Municipality. Unpublished MRT Dissertation, University of Zululand, KwaDlangezwa.

BMF [Black Management Forum] 2003: Review Employment Equity. Submission of the BMF to the Portfolio Committee on Labour Matters. Johannesburg: BMF (I 4 May 2003).

Brown, A., 2005, 'Empowerment Charters are a site of struggle' Umrabulo, Number 22, February 2005

Cowan, G.I., Yawitch, J. \& Swift, M. [Eds]. 2003. Strategic innovations in biodiversity conservation: The South African experience. Department of Environmental Affairs and Tourism [DEAT], Pretoria.

Dawes, N. (2004): National operator. The Mail and Guardian, December 17, 2004. Vol. 20/ No 5I(2-3).

DEAT [Department of Environmental Affairs and Tourism], (1996): White Paper: The development and promotion of tourism in South Africa. Pretoria: Government Printers of South Africa, DEAT.

DEAT [Department of Environmental Affairs and Tourism], (1998): Tourism in GEAR Development Strategy I999-2000. DEAT, Pretoria.

DEAT [Department of Environmental Affairs and Tourism], 2000: Unblocking delivery on tourism strategy by Government Departments. DEAT, Pretoria.

DEAT [Department of Environmental Affairs and Tourism], 2004: The global tourism competitiveness project. Pretoria: DEAT.

DEAT [Department of Environmental Affairs and Tourism], 2006: People-planet-prosperity: A strategic framework for sustainable tourism development in South Africa. Pretoria: DEAT.

De Villiers, R. 2005: The Battle of Black Economic Empowerment Business: Innovation or Entrepreneurship. Entrepreneur SA, February 2005.

DTI [Department of Trade and Industry], (2003): South Africa's economic transformation: A strategy for Broad-Based Economic Empowerment, DTI, Pretoria.

DTI [Department of Trade and Industry], (2004a): Broad-Based BEE Framework: Principles and Definitions. Government of South Africa, Pretoria.

DTI [Department of Trade and Industry], (2004b): The role of equity ownership in Broad-Based Economic Empowerment. DTI, Pretoria.

Glennie, M. (2004): Is Black Economic Empowerment serious? The Enterprise: [10 Years of Empowerment Special Edition]. Johannesburg: Black Enterprise Publishers

Jack, V. 2008: Black Directors at Listed Companies Inch up to 24 Percent. Sunday Tribune - Business Report. Sunday 28 September, 2008.

Lalu A. 2004: The Pillars of BEE Framework. Black Business Quarterly. Cape Media. Vol. 7 (2): 59-60.

Lediga, C. 2006: Empowerment needs entrepreneurship too. Sunday Times: (Business times). 19 November, 2006.

Lubbe, B.A. 2003. Tourism management in Southern Africa. Maskew Miller Longman (Pty) Ltd. Cape Town.

Mabotja, S. 2006: Incisive critique on the state of BEE. City Press: (Business). 10 September, 2006.

Magakgala, M. 2003: Main streaming protected areas. In Cowan, G.I., Yawitch, J. \& Swift, M. [eds]. Strategic innovations in biodiversity conservation: The South African experience. 14-20. Department of Environmental Affairs and Tourism [DEAT], Pretoria.

Magi, L.M. (1999): Township Recreation Patterns and the new order in South Africa. Tourism Geographies. Vol.I (3): I42-I63.

Magi, LM. 2000: People, Recreation and the Environment. In Fox, R \& Rowntree, K. [Ed.] The Geography of South Africa in a Changing World. Oxford University Press, Cape Town, pp $439-456$.

Inkanyiso, Jnl Hum \& Soc Sci 2010, 2(2) 
Magi, LM. 2007: To recreate or conserve, that is the question: The case of Lake St Lucia. Journal of Tourism and Hospitality. 4 (2): I12.

Matola, M. (2005): What, where and when in the Zulu Kingdom: An official guide to events and entertainment. Brochure of Tourism KwaZulu-Natal. (4 April 2005)

Milazi, M. 2008: Markets wipe out BEE gains. Sunday Times - Business Times, Money. 12 October, 2006.

Monama, M. 2006: Big stake in BEE rating. City Press: (Business). 10 September, 2006.

Mowforth, M. \& Munt, I. (1998): Tourism and Sustainability. London: Routledge.

Nzimande, B. \& Sikhosana, M. 1996: Affirmative action and Transformation. Creda Press, Durban.

Peacock, B. 2006: Determining BEE success. Sunday Times (Business Times). 20 May, 2006.

Pigram, J. J. (1983): Outdoor Recreation and Resource Management. St Martin's Press, New York.

Qunta, C. (2004): Is BEE the Empowerment of the Few: Separating Myth from Reality. In Ebersohn W (2004): Empowering the Majority. The Black Management Forum Conference.

Radebe, P. 2008: Small business is the missing middle in banks' service target. The Mercury - Business Report. 14 October, 2008.

Ramphele, M. 2008. Laying ghosts to rest: Dilemmas of the transformation in South Africa. Cape Town: Tafelberg.

Roberts, S., Chabane, N., \& Goldstein, A., 2005: The changing face and strategies of big businesses in South Africa. Paper from the Corporate Strategy and Industrial Development Research Programme. University of Witwatersrand, Johannesburg.

Rogerson, C.M. \& Visser, G. 2004: Tourism development issues in contemporary South Africa. Africa Institute of South Africa, Pretoria.

Ryan, E. 2006: Can't find empowered suppliers? Build them yourself from scratch. Sunday Times: (Business times). 19 November, 2006.

SAGG [South African Government Gazette] (2004): Broad-Based Black Economic Empowerment Act 53, 2003. Pretoria: Government of South Africa.

SAT [South African Tourism] 2004: Tourism growth strategy [S.A.]: Gearing up to be globally competitive. South African Tourism: Johannesburg.

Sikhakhane, J. 2006: Current BEE state of mind is mockery of Mandela's dream. Business Report. 10 October 2006.

Spenceley, A., Goodwin, H., \& Maynard, W. 2004: Development of responsible tourism guidelines for South Africa. In Diamantis, D. [ed]. Ecotourism: Management and Assessment. 28I-297. Thomson Learning, London.

Spykes P. (2002): South African Tourism Industry Empowerment and Transformation Annual Review. Cape Town. Letsema and Infonomics.

Vilakazi, A. D. 2008: Black entrepreneurial development in the tourism industry: initiatives within the Greater Durban Metropolitan Area. Unpublished MRT Dissertation, University of Zululand, KwaDlangezwa.

Viljoen, J. 2007. Rural tourism hampered by national marketing. HSRC Review 5 (4): I8- 19.

Viljoen, J. \& Tlabela, K. 2006. Rural tourism development is South Africa. Human Sciences Research Council. Pretoria.

Vivian, K. \& Hall, D. (1994): Tourism: A gender analysis. New York: Wiley and Son Publishers.

Wahab, S. 2000. Sustainable tourism in the developing world. In Wahab, S. \& Pigram, J.J. [eds]. Tourism, development and growth: The challenge of sustainability. 129-146. Routledge. London.

Wall, G. 2000. Sustainable tourism - unsustainable development. In Wahab, S. \& Pigram, J.J. [eds]. Tourism, development and growth: The challenge of sustainability. 33-49. Routledge. London.

Williams, A. M. and Shaw, G. (1998): Tourism Economic Development: European Experience. London: Wiley and son Ltd.

\section{Websites}

http://www.en.wikipedia.org/wiki/broad_based_black_economic_empowerment. (2007): [Online] Broad Based Black Economic Empower-ment. Website [Accessed on 04-10-2007]

http://www.en.wikipedia.org/wiki/Tourism. (2007): [Online] Strategy (Defined). Website [Accessed on 04- 10-2007].

http://www.gautengonline.gov.za/miscimages/bbbee/bbbeeStrategy (2008): [Online] Gauteng Provincial Tourism - A Strategy For Broad-Based Black Economic Empowerment. Website [Accessed on 14-10-2008]

http://www.labour.gov.za. (2008): [Online] Website of the Department of Labour, South Africa. [Accessed on I4-10-2008]

http://www.tourismvi.ca/org/stakeholder. (2008): [Online] Tourism Vancouver Island - What is a stakeholder model. Website

[Accessed 14-04-2008]. 